\title{
Do employees with flexible contracts receive less training?
}

Citation for published version (APA):

Jonker, N., \& de Grip, A. (1999). Do employees with flexible contracts receive less training?

Researchcentrum voor Onderwijs en Arbeidsmarkt, Faculteit der Economische Wetenschappen. ROA Research Memoranda No. 1E https://doi.org/10.26481/umaror.199901E

Document status and date:

Published: 01/01/1999

DOI:

10.26481/umaror.199901E

Document Version:

Publisher's PDF, also known as Version of record

\section{Please check the document version of this publication:}

- A submitted manuscript is the version of the article upon submission and before peer-review. There can be important differences between the submitted version and the official published version of record.

People interested in the research are advised to contact the author for the final version of the publication, or visit the DOI to the publisher's website.

- The final author version and the galley proof are versions of the publication after peer review.

- The final published version features the final layout of the paper including the volume, issue and page numbers.

Link to publication

\footnotetext{
General rights rights.

- You may freely distribute the URL identifying the publication in the public portal. please follow below link for the End User Agreement:

www.umlib.nl/taverne-license

Take down policy

If you believe that this document breaches copyright please contact us at:

repository@maastrichtuniversity.nl

providing details and we will investigate your claim.
}

Copyright and moral rights for the publications made accessible in the public portal are retained by the authors and/or other copyright owners and it is a condition of accessing publications that users recognise and abide by the legal requirements associated with these

- Users may download and print one copy of any publication from the public portal for the purpose of private study or research.

- You may not further distribute the material or use it for any profit-making activity or commercial gain

If the publication is distributed under the terms of Article $25 \mathrm{fa}$ of the Dutch Copyright Act, indicated by the "Taverne" license above, 


\title{
Do Employees with Flexible Contracts receive less Training?
}

\author{
ROA-RM-1999/1E
}

Nicole Jonker* and Andries de Grip

* Faculty of Economics and Econometrics, University of Amsterdam, Amsterdam, The Netherlands. The authors wish to thank Lex Borghans, Hans Heijke and Michel van Smoorenburg for useful suggestions and comments on earlier versions of this paper.

Research Centre for Education and the Labour Market

Faculty of Economics and Business Administration

Maastricht University

Maastricht, March 1999 
Abstract

1 Introduction 1

2 Relation-specific human capital 2

3 The Model $\quad 4$

4 Data and selected variables $\quad 6$

5 Estimation Results 9

6 Conclusion $\quad 12$

$\begin{array}{ll}\text { References } & 13\end{array}$

$\begin{array}{ll}\text { Appendix A } & 17\end{array}$ 


\begin{abstract}
For the growing group of flexible workers, further investments in their human capital are even more important than for employees with permanent contracts, because the labour market position of flexible workers is continuously at risk. In this paper, we analyse the participation rate of flexible employees in company training. We will simultaneously estimate the determinants of receiving continuing vocational training and the duration of this training in a sample selection model. The estimation results indicate that flexible employees receive about half as much training with the current employer than permanent employees. A Blinder-like decomposition analysis shows that $40 \%$ of this difference is due to the fact that employers are more willing to invest in the human capital of permanent employees. However, flexible workers who do get training participate in training of at least the same duration as that of the permanent employees.
\end{abstract}




\section{Introduction}

Company training becomes more and more important. In 1986, one in every four Dutch employees took a training course. This ratio of training participation increased to 0.33 in 1990 and 0.35 in 1993 (CBS, 1995). The participation in training activities may be important for various reasons: (1) to bridge any gaps between skills requirements and educational attainment (Barron, Black and Loewenstein, 1989 and Van Eijs and Heijke, 1999), (2) to prevent skills obsolescence (De Grip et al., 1997 and OECD, 1998) and (3) to increase career opportunities (cf. e.g. Bartel, 1992, Prendergast, 1993 and De Grip et al., 1998).

A lower rate of investment in training may weaken the labour market position of employees. This problem is even more serious for groups of employees who already have a weak labour market position, such as workers with little education and workers with flexible contracts. This 'flexible labour force' is growing in the Netherlands: in $19927.6 \%$ of the employees on the Dutch labour market had a flexible contract, which figure increased to $10.8 \%$ in 1997 (CBS, 1998).

In some studies, investment in training and temporary contracts are classified as two opposing 'flexibility strategies' of firms. Delsen (1995) distinguishes between external flexibility - i.e. the ability of firms to vary the number of workers - and internal flexibility, i.e. the ability of firms to change the quality of employment by retraining and re-assignment and of workers. Treu (1992) distinguishes between short-term labour flexibility facilitated by temporary contracts and longterm flexibility established by creating a system of permanent learning (Den Broeder, 1996).

In this paper, we will investigate if flexible contracts and investment in company training are mutually exclusive human resources strategies. We will therefore analyse which factors affect the probability of attending company training or other forms of off-the-job training. This has already been done in various other studies (see e.g. Altonji and Spletzer, 1991; Green, 1993; Groot and Oosterbeek 1995; Veum, 1996). The new element in this paper is the focus on employees with flexible contracts. Firms are expected to be unwilling to invest in the relationspecific human capital of these employees because the firms will probably not receive the benefits of their training.

It is also possible that employees with flexible contracts attend training courses of a lesser quality than their colleagues with permanent contracts. We here assume that the duration of a training course is positively correlated with the quality of the training: one will learn more from a one-year course with homework than from a course which takes only a few days. We will therefore also analyse whether flexible employees attend training courses of a shorter duration than permanent employees. A sample selection model has been used to simultaneously estimate the probability of attending a training course and the duration of that training course. If flexible employees appear to have a significantly lower chance of attending a training course, we will use a "Blinder-like" approach to see whether this lower training participation is caused by the characteristics of this group or by other effects. 
Another new feature in this paper, compared to the other studies on training participation, is that we analyse the effects of the use of information technology (IT) on the probability of participating in training. The inclusion of such a variable in an analysis of the determinants of training participation may be an important reason for investments in additional training because of the rapid diffusion of information technology in all economic sectors. People who have an information technology intensive job run the risk of getting obsolete human capital if they do not keep up their skills by means of additional training.

The remainder of this paper is structured as follows: In Section 2, we will discuss the relationspecific human capital model, from which the hypothesis can be derived that employees with flexible contracts receive less training than workers with permanent employment contracts. Section 3 describes the sample selection model that is used for the simultaneous estimation of the probability of attending training and the duration of training. In this section, we also calculate the 'Blinder-decomposition' of the training differential between flexible and permanent employees. This analysis enables us to determine to what extent this training differential is due to differences in the characteristics of workers and to what extent it is due to the fact that firms are less willing to invest in the training of flexible workers, even if they have similar personal characteristics as the permanent workforce. Section 4 gives a description of the data and the variables used, while Section 5 discusses the estimation results. Section 6 contains the conclusions.

\section{Relation-specific human capital}

The central principle of the human capital theory is that the skills, knowledge and understanding that are acquired in training represent human capital, which is valued by employers because it leads to higher productivity (Becker, 1975). As with other investment plans, it is possible to carry out cost-benefit analyses, for example with the net present value or internal rate of return methods (Psacharopoulos, 1987).

Employers will invest in the training of their workers if the expected rate of return from the investment in training is higher than the alternative rate of return on investments with a similar risk (for example, the market interest). Of course, the expected rate of return on training for the firm is dependent on the training costs, but also on the investment horizon, the increase in productivity and the increase in wage costs. According to the internal rate of return method, the rate of return on an investment in training can be calculated as the rate at which the net present value of the costs is equal to the net present value of the returns. In that case the returns are the increase in productivity, while the costs consist of wage costs and training costs (out-of-pocket costs + lost productivity during the training period). The rate of return for the employer $\left(r_{e}\right)$ from an investment in employee training is dependent on the increase of productivity in the employer's organisation $\left(\Delta \mathrm{P}_{\mathrm{e}}\right)$, the wage increase $(\Delta \mathrm{W})$, the training costs paid by the firm $\left(\mathrm{TC}_{\mathrm{e}}\right)$ and the number of years the employee is expected to remain in the organisation $\left(\mathrm{Y}_{\mathrm{e}}\right)$, as shown in formula (2.1): 


$$
T C_{e}=\sum_{n=0}^{n=y_{e}} \frac{\Delta P_{e}-\Delta W}{\left(1+r_{e}\right)^{n}}
$$

According to human capital theory, the employee's motivations to undertake training do not differ fundamentally from the employer's motivations. Equation (2.2) is therefore very similar to the first equation, except that the increase of productivity is irrelevant for the employee and that the wage increase is a return rather than a cost. The rate of return on an investment in training for the worker $\left(r_{w}\right)$ is dependent on the wage increase $(\Delta \mathrm{W})$, the training costs paid by the worker $\left(\mathrm{TC}_{\mathrm{w}}\right)$ and the number of years the employee expects to remain in the labour market $\left(\mathrm{Y}_{\mathrm{w}}\right)$.

$$
T C_{w}=\sum_{n=0}^{n=y_{w}} \frac{\Delta W}{\left(1+r_{w}\right)^{n}}
$$

For both employees and employers, the investment horizon, e.g. $Y_{w}$ and $Y_{e}$ respectively, is particularly important in determining the amount of training investments. For a given level of training costs, and given training benefits per period, the shorter the (expected) investment horizon is, the lower the internal rate of return on the investment will be. An employer will therefore be less likely to train employees with temporary contracts, because of the higher risk that such employees will leave the firm relatively soon.

However, it is the expected investment horizon which is relevant for training investment decisions. Employers who expect e.g. that women will withdraw from employment sooner than men will calculate a lower expected internal rate of return for women (see also Groot et al., 1988). One difference between the expectations of the employer and the expectations of the employee is the fact that an employer is interested in how long a trained employee can be expected to remain within the employer's own organisation, whereas employees will base their decisions on how long they expect to remain in the labour market: $\mathrm{Y}_{\mathrm{e}} \mathrm{O} \mathrm{Y}_{\mathrm{w}}$.

Human capital literature in particular focuses on the difference between general and firmspecific training, in order to emphasise the difference between training that raises the productivity of the worker for more firms, and training that has no effect on the workers' productivity if they switch to another firm. Becker's (1962) argument that firms are only prepared to invest in firm-specific human capital was later modified by e.g. Hashimoto (1981), Katz and Ziderman (1990), Stevens (1994 a, b), Booth and Chatterji (1995), and Booth and Snower (1996). These more recent studies indicate in particular that not all training can simply be decomposed into general and specific components, since a training course usually has a mixed character, in the sense that it comprises both general and firm-specific elements. Stevens (1994 b) argues that when training is transferable among firms that have some market power in setting wages, the potential benefits from training are not only for the firm providing it and the worker acquiring it, but also for other firms that can poach the trained workers. And since some of the benefits from training falls on the poachers, there is no way for the worker 
demanding the training and the firm supplying it to capture all the rewards from this training. Inevitably this leads to an underinvestment in training.

Crawford (1988 and 1990) analyses the training investments in the more general context of relation-specific capital, i.e. capital the productivity of which depends on the continuation of the relationship:

"Becker's analysis of investment incentives greatly overstates the ease with which the problems he studied are solved in practice. Paying for his own training would often require a worker to finance his consumption for several years by borrowing in a highly imperfect capital market" (Crawford, 1988, p. 486).

If there is no long-term contract to commit to future compensation for sunk-costs of training investments, the firm and the worker will agree to underinvest. Temporary contracts will therefore lead to a lower participation in training.

\section{The Model}

We use the sample selection model to analyse the chance of attending company training and the duration of the training simultaneously. This model is described in e.g. Amemiya (1989) and Maddala (1993). The advantage of simultaneously estimating the chance of attending training and the duration of training is that it is possible to estimate the duration while correcting for the fact that employees and people choose to participate in a training course, because this is beneficial for them (e.g. to become more productive, to obtain better career opportunities, et cetera.) So the duration of training is only observed if one decides to attend a training course and will therefore be censored and only observed when it is greater than zero. If we did not correct for the censoring of duration, but simply tried to explain the duration of training by using e.g. OLS regression, we would get inconsistent estimates. By using the sample selection model, we get consistent estimates of the coefficients and of the standard errors of these estimates. The sample selection model can be described as follows:

latent choice variable:

$$
\begin{array}{lll}
y_{i}=1 & ] & y_{i}^{*}=Z_{1 i} \gamma_{1}+\epsilon_{1 i}>0 \\
y_{i}=0 & ] & y_{i}^{*}=Z_{1 i} \gamma_{1}+\epsilon_{1 i}<=0
\end{array}
$$

duration of training:

$$
\begin{aligned}
& d_{i}=Z_{2 i} \gamma_{2}+\epsilon_{2 i} \\
& d_{i} \text { is only observed if } y_{i}=1
\end{aligned}
$$

The latent choice variable $y_{i}^{*}$ is explained by a number of factors that are stored in the vector $z_{1 i .}$. If $y_{i}{ }_{i}$ is positive then employee $i$ has attended a training course $\left(y_{i}=1\right)$, otherwise he has not attended one $\left(y_{i}=0\right)$. The duration of the training in weeks $\left(d_{i}\right)$ is explained by some factors stored in the vector $Z_{2 \mathrm{i}}$. We assume that the error terms $\varepsilon_{1 \mathrm{i}}$ and $\varepsilon_{2 \mathrm{i}}$ follow a bivariate normal distribution with mean zero and covariance matrix 
$\Sigma=\left[\begin{array}{ll}\sigma_{11} & \sigma_{12} \\ \sigma_{21} & \sigma_{22}\end{array}\right]$

In order to determine the likelihood function, we distinguish two groups. The first group consists of employees who have not attended company training i.e. $\varepsilon_{1 \mathrm{i}}<=-\mathrm{Z}_{1 \mathrm{i}} \gamma_{1}$ and $\mathrm{d}_{\mathrm{i}}$ is not observed. The second group consists of employees who have attended company training and whose training duration is known i.e. $\varepsilon_{1 i}>-Z_{11} \gamma_{1}$ and $\varepsilon_{2 i}=d_{i}-Z_{2 i} \gamma_{2}$. If we denote the joint density function of the error terms $\varepsilon_{1 \mathrm{i}}$ and $\varepsilon_{2 \mathrm{i}}$ by $\mathrm{f}\left(\varepsilon_{1 \mathrm{i}}, \varepsilon_{2 \mathrm{i}},\right)$ the basic likelihood function will be:

$$
\begin{aligned}
L= & \prod_{y=0}\left\{P\left(y_{i}=0\right)\right\} \prod_{y=1}\left\{f\left(y_{i}=0, d_{i}\right)\right\}= \\
& \prod_{y=0}\left\{P\left(\epsilon_{1 i} \#-Z_{1 i} \gamma_{1}\right)\right\} \prod_{y=1}\left\{\int_{Z_{1 i} \gamma_{1}}^{4} f\left(\epsilon_{1 i} \epsilon_{2 i}=d_{i}-Z_{2 i} \gamma_{2}\right) \mathrm{M} \epsilon_{1 i}\right\}= \\
& \left.\prod_{y=0}\left\{\Phi\left(-Z_{1 i} \gamma_{1} \sigma_{1}^{-1}\right)\right\} \prod_{y=1}\left\{\sigma_{2}^{-1} \phi\left(\sigma_{2}^{-1}\left(d_{i}-Z_{2 i} \gamma_{2}\right)\right) *\left(\left(-Z_{1 i} \gamma_{1} \sigma_{1}^{-1}\right)+\left(\rho \sigma_{2}^{-1} *\left(d_{i}-Z_{2 i} \gamma_{2}\right)\right)\right) *\left(1-\rho^{2}\right)^{-0.5}\right)\right\}
\end{aligned}
$$

The derivation of equation 3.3 is given in, for example, Maddala (1983) and Amemiya (1989). The density function and the distribution function of the standard normal distribution function are denoted as usual by $\phi($.$) and \Phi\left(\right.$.) respectively. The variance $\sigma_{11}$ is normalised to one, otherwise only $\gamma_{1} / \sigma_{1}$ would be identified (see Amemiya 1989, pp. 386), $\rho$ is equal to $s_{12} / s_{1} s_{2}$. It should be smaller than one (in absolute value) in order to have an estimable likelihood function. By taking the natural logarithm of equation 3.3 one gets:

$\ln \mathrm{L}=$

$$
\begin{aligned}
& \sum_{y=0}\left\{\ln \left(\Phi\left(-Z_{1 i} \gamma_{1} \sigma_{1}^{-1}\right)\right)\right\}+ \\
& \sum_{y=1}\left\{-\ln \left(\sigma_{2}\right)+\ln \left(\phi\left(\sigma_{2}^{-1}\left(d_{i}-Z_{2 i} \gamma_{2}\right)\right)\right)+\ln \left(\Phi\left(\left(Z_{1 i} \gamma_{1}\right)+\left(\rho \sigma_{2}^{-1}\left(d_{i}-Z_{2 i} \gamma_{2}\right)\right) *\left(1-\rho^{2}\right)^{-0.5}\right)\right)\right\}
\end{aligned}
$$

Among the explanatory variables in the model, we focus in particular on the effects of having a flexible contract. As argued in Section 2, we expect a negative sign on both training participation and training duration. Moreover, we analyse the effects of information technology (IT) on the probability of training participation. As the diffusion of IT is expected to be an important reason for investments in additional training, we expect a positive sign for this variable. In a similar way, we expect that high-tech sectors (R\&D intensive) require more investments in the training of their workforce than low-tech sectors. Another argument for more training investments could be that workers are forced to retrain themselves for another occupational field, as they are employed in an occupation which faces shrinking employment. 
For this variable, we therefore also expect a positive sign in the training participation equation. However, due to the increased uncertainty of holding one's job, there could also be a negative effect on the training participation of workers employed in an occupation with shrinking employment. Lastly, we control for the various worker characteristics as in other studies on training participation (Cf. Green, 1993 and Groot and Oosterbeek, 1995).

\section{Data and selected variables}

For the empirical analysis, the Dutch OSA biannual labour supply survey 1994 is used. This is the last survey of six waves. Most questions in this survey concern the respondents' situation in the period 1992-1994. However, some of the questions refer to the entire labour market history of the respondent, such as the previous training activities of the respondent.

The dataset consists of 4,538 observations, all of which belong to the potential labour force. The subsample used in the analysis is restricted to people in employment (except the selfemployed). After elimination of observations with missing values on essential variables, 2,279 observations could be used in the analysis, 98 observations have a flexible contract, whereas 2,181 have a permanent contract. The permanent workforce is here defined as the employees who have a permanent contract or a temporary contract with prospects of a permanent contract.

The data show that about one third of the workers participated in training activities in the period during which they held their job with the current employer. However, there are large differences in training participation between flexible workers and workers with permanent contracts. About $39 \%$ of the permanent employees participated in training, whereas only $22 \%$ of the flexible workers did. This does not necessarily mean that flexible employees received less training than permanent employees, because we only take into account the company training with the current employer and flexible employees have shorter tenures than permanent employees. This effect will be corrected for in our empirical model

The stylised facts presented in Table 1 show that firms are indeed less willing to invest in the training activities of their flexible workforce. Participation in training of permanent employees is paid by the employer in almost three times as many cases than the training of flexible employees. So flexible workers will have to invest in training themselves in order to prevent skill obsolescence or to increase their career opportunities.

In the model estimated, there are two dependent variables, namely the dummy variable training participation which is equal to one if one participated in one or more training courses between 1989 and 1994 with the current employer, and the continuous variable training duration which measures the duration in weeks of the most recently attended training in the period 1989-1994 with the current employer if one has attended a training during this period. 
Table 1

Who pays for the training?

\begin{tabular}{lcc}
\hline Financial support & $\begin{array}{c}\text { Permanent } \\
\text { workers } \\
\%\end{array}$ & $\begin{array}{c}\text { Flexible } \\
\text { workers } \\
\%\end{array}$ \\
\hline Employer & 82 & 28 \\
Employment agency & 1 & 5 \\
Someone else & 2 & 8 \\
No support, paid oneself & 15 & 59 \\
Total & 100 & 100 \\
\hline
\end{tabular}

Source: OSA Labour Supply Survey, 1994

The following explanatory variables are used in our estimations:

\section{Personal characteristics}

Age: in years;

- Female: dummy variable equal to one if the respondent is female;

- Education: nominal number of years of education of the respondent's highest level of initial education, ranging from 0 (only primary school) to 12 (university degree);

- Primary school: dummy variable equal to one if the respondent's highest education is primary school;

- LVE/LGSE: dummy variable equal to one if the respondent's highest education is Lower Vocational Education or Lower General Secondary Education (reference);

. IVE/HGSE: dummy variable equal to one if the respondent's highest education is Intermediate Vocational Education or Higher General Secondary Education;

- HVE: dummy variable equal to one if the respondent's highest education is Higher Vocational Education;

. University: dummy variable equal to one if the respondent's highest education is university;

- Experience: number of years worked (paid) by the respondent; 
- Ten 1: dummy variable equal to one if one has worked 0-1 year at the current employer ${ }^{1}$;

- Ten 2: dummy variable equal to one if one has worked 1-2 year at the current employer;

- Ten 3: dummy variable equal to one if one has worked 2-3 year at the current employer;

- Ten 4: dummy variable equal to one if one has worked 3-4 year at the current employer;

- Ten 5: dummy variable equal to one if one has worked more than 4 years at the current employer (reference);

- Flexible: dummy variable equal to 1 if one has a flexible labour contract;

- Tenure: number of years with the current employer;

- Hours worked: number of hours worked per week according to the labour contract;

- Job level: A variable which ranges from 1 to $5 ; 1$ indicates that one has an elementary occupation and 5 indicates that one has a professional on scientific job;

- Shrinking occupation: dummy variable equal to 1 if one works in an occupational class that had a declining employment in the period 1988-1991;

- IT: variable which measures the use of information technology in the respondent's occupational class relative to the use of information technology in other occupational classes (see De Graaf et al 1995).

\section{Employer characteristics}

- Firm size 1 : dummy variable equal to 1 when one works in an organisation with less then 10 employees;

- Firm size 2 : dummy variable equal to 1 when one works in an organisation with 10-99 employees (reference);

- Firm size 3 : dummy variable equal to 1 when one works in an organisation with 100 or more employees;

- R\&D: percentage jobs devoted to research and development related to the total number of jobs per branch of industry in 1992 in full-time equivalents (see Brouwer and Kleinknecht,1994).

Appendix A shows the means and standard deviations of the variables used (separately for flexible and permanent workers).

1. The variables Ten 1..Ten 5 are used to correct for the "different observation periods" at the current employer in the period 1989-1994, e.g. employees who have been working in a firm for only one year have a lower probability of having attended a training course at the current employer than employees who have been working for their current employer the whole observation period, other things equal. The continuous variable 'tenure', on the other hand, is the explanatory variable that measures the effect of tenure on the probability of having received training. 


\section{Estimation Results}

Table 2 contains the estimation results of the sample selection model. The estimation results show that flexible employees participate significantly less in training than employees with a permanent contract, even if we control (using the variables Ten1 to Ten4) for the proportion of time they have been working with their current employer between 1989-1994. This is what was expected from the relation-specific human capital model. It indicates that these people are not in a favourable labour market position; their current job is considered to be temporary and they receive less training than permanent employees, which lowers their career opportunities.

Table 2

Estimation results sample selection model (absolute t-values between parentheses)

\begin{tabular}{|c|c|c|c|c|}
\hline \multirow{2}{*}{$\begin{array}{l}\text { Variable } \\
\text { Constant }\end{array}$} & \multicolumn{2}{|c|}{$\begin{array}{l}\text { Training participation } \\
\text { coefficient } \quad \text { (t-value) }\end{array}$} & \multicolumn{2}{|c|}{$\begin{array}{l}\text { Training duration } \\
\text { coefficient } \quad \text { (t-value) }\end{array}$} \\
\hline & ! 0.394 & $(1.459)$ & 49.999 & $(2.338)^{*}$ \\
\hline Female & 0.115 & (1.466) & ! 5.962 & (1.302) \\
\hline Age & ! 0.020 & $(3.446)^{\star *}$ & 0.493 & $(1.121)$ \\
\hline Primary school & 0.082 & $(0.815)$ & - & - \\
\hline IVE/ HGSE & 0.066 & $(0.889)$ & - & - \\
\hline HVE & 0.093 & $(0.865)$ & - & - \\
\hline University & 0.014 & $(0.079)$ & - & - \\
\hline Education (years) & - & - & ! 1.562 & (1.605) \\
\hline Experience & 0.005 & $(0.808)$ & ! 1.446 & $(3.296)^{\star *}$ \\
\hline Job level & 0.155 & $(3.613)^{\star \star}$ & 0.997 & $(0.305)$ \\
\hline Flexible contract & 0.385 & $(2.364)^{*}$ & 8.293 & $(0.684)$ \\
\hline Ten1 & ! 0.506 & $(4.013)^{\star \star}$ & - & - \\
\hline Ten2 & 0.434 & $(3.713)^{\star \star}$ & - & - \\
\hline Ten3 & 0.205 & $(1.880)$ & - & - \\
\hline Ten4 & 0.484 & $(0.429)$ & - & - \\
\hline Tenure & 0.941 & (1.767) & 0.539 & (1.636) \\
\hline Hours worked & 0.013 & $(3.348)^{\star \star}$ & 0.061 & $(0.196)$ \\
\hline Shrinking occupation & 0.088 & $(1.274)$ & - & - \\
\hline IT & 0.111 & $(3.370)^{\star *}$ & - & - \\
\hline Firm size 1 & ! 0.225 & $(2.025)^{*}$ & 9.023 & $(1.220)$ \\
\hline Firm size 3 & 0.202 & $(2.994)^{\star \star}$ & ! 6.629 & (1.504) \\
\hline$R \& D$ & 0.035 & $(1.385)$ & ! 1.663 & $(0.864)$ \\
\hline $\mathrm{s}_{2}$ & & & 46.7 & $(3.941)^{\star \star}$ \\
\hline r & & & ! 0.122 & $(0.130)$ \\
\hline Number of cases & 2,253 & & & \\
\hline Log-likelihood & ! 5,816 & & & \\
\hline
\end{tabular}

This implies that if these people do not get a permanent job within a few years, their human capital will probably deteriorate, which could result in bad jobs or unemployment.

As expected, the use of information technology has a positive effect on training participation. 
This is in line with the rapid developments in information technology and shows that for the workers employed in these jobs, it is important to keep their knowledge of IT up to date by additional training. However, the estimation results do not significantly indicate that workers employed in the R\&D intensive sectors of industry participate more in training activities than other workers. Also, workers employed in a shrinking occupation do not participate significantly more in training than others. This indicates a lack of retraining activities for workers who run the risk of losing their jobs. Employees of large organisations have a higher chance of attending training than employees of small organisations. From an investment point of view, it is remarkable that women have an (insignificant) higher probability of training participation than men, although Oosterbeek (1996) also finds evidence that females attend more training. As expected, employees with much labour market experience and/or a long tenure, participate (insignificantly) less often in training than others. Employees with a high job level participate more in training than employees with an intermediate or low job level. People who work full time participate more in training activities than part-time workers. This is exactly what human capital theory predicts: employees and employers will be more willing to invest in their human capital the more time they have to capture the benefits of the training.

The estimation of the training duration equation shows only two significant variables. The estimated value of $\rho$ is negative and insignificant. This result implies that the simultaneous estimation of training participation and training duration was not necessary. If employees with a flexible contract receive training, they participate in training of about the same length as employees with a permanent contract. Only the labour market experience of the workers has a significant effect on the length of the training course. People with much experience attend shorter training courses than people with only little experience. As mentioned above, this is quite reasonable because older employees have more human capital than younger workers and only have to participate in courses in order to avoid skill obsolescence, whereas younger people still have to invest in new human capital to extend their career opportunities. Another reason may be that older workers and employers of older workers have less time to receive the benefits of the training of old and experienced workers than from the training of young workers (this reason may be especially important if the employer pays the training costs).

\section{Blinder-decomposition of the training differential}

The lower probability of training participation for flexible workers indicates that there is a smaller incentive to invest in training activities for flexible workers. In order to calculate the "Blinder decomposition" of the training differential between flexible and permanent employees, we have to estimate the training equation for both groups separately. ${ }^{2}$ Our Blinder

2. Having a flexible contract may, however, be endogenous. Employees who are very attractive for employers are offered fixed contracts and their employers may be willing to invest a great deal in them, whereas employees who face difficulties in finding a job may be offered the less attractive flexible contracts with the possibility of less favourable training options. There are several ways to deal with this 'selection bias', such as using an IV-like predictor or using switching regression (see e.g. Maddala, 1983). However, since there are relatively few flexible workers in our data set, it is not 
decomposition is somewhat different from the usual decomposition. We decompose the training differential in a characteristics differential and a coefficients differential in the following way:

$\Phi\left(X_{p} \beta_{p}\right)-\Phi\left(X_{f} \beta_{f}\right)=\left(\Phi\left(X_{p} \beta_{p}\right)-\Phi\left(X_{f} \beta_{p}\right)\right)+\left(\Phi\left(X_{f} \beta_{p}\right)-\Phi\left(X_{f} \beta_{f}\right)\right)$

where the mean values of the explanatory variables of the flexible and the permanent employees are stored in de vector $X_{f}$ and $X_{p}$ respectively and the estimated coefficients of Table 3 are stored in the parameter vectors $\beta_{f}$ and $\beta_{p}$. $\Phi($.$) denotes the standard normal$ cumulative

Table 3

Separate training equations for flexible and permanent employees (absolute t-values between parentheses)

Variable

Permanent employees coefficient
Flexible employees coefficient

$\begin{array}{lllll}\text { Constant } & ! 0.409 & (1.47) & ! 1.885 & (1.14) \\ \text { Female } & 0.127 & (1.63) & ! 0.198 & (0.40) \\ \text { Age } & ! 0.021 & (3.43)^{* *} & ! 0.006 & (0.20) \\ \text { Primary school } & ! 0.063 & (0.63) & ! 0.074 & (0.12) \\ \text { IVE/pre HVE/pre university } & 0.044 & (0.59) & 0.798 & (1.62) \\ \text { HVE } & 0.091 & (0.85) & 0.585 & (0.75) \\ \text { University } & 0.034 & (0.19) & 0.382 & (0.33) \\ \text { Experience/100 } & ! 0.349 & (0.58) & ! 2.947 & (0.66) \\ \text { Job level } & 0.158 & (3.76)^{* *} & 0.074 & (0.26) \\ \text { T en 1 } & ! 0.526 & (4.02)^{* *} & ! 0.800 & (0.81) \\ \text { Ten 2 } & ! 0.377 & (3.26)^{* *} & ! 0.457 & (0.50) \\ \text { T en 3 } & ! 0.191 & (1.72) & ! 0.876 & (0.87) \\ \text { T en 4 } & 0.030 & (0.27) & 0.761 & (0.75) \\ \text { Tenure/100 } & ! 0.998 & (1.90) & ! 7.432 & (0.62) \\ \text { Hours worked } & 0.014 & (3.35)^{* *} & 0.027 & (1.48) \\ \text { Shrinking job class } & 0.072 & (1.03) & 0.854 & (1.79) \\ \text { IT } & 0.120 & (3.61)^{* *} & ! 0.365 & (1.56) \\ \text { Firm size 1 } & ! 0.206 & (1.83) & 0.709 & (1.15) \\ \text { Firm size 3 } & 0.225 & (3.37)^{* *} & 0.191 & (0.42) \\ \text { R \& D } & 0.029 & (1.22) & 0.080 & (0.52)\end{array}$

Number of cases

${ }^{*}$ significance at $5 \%$ level ${ }^{* \star}$ significance at $1 \%$ level

distribution function. The first term in brackets to the right of the equal sign represents the

possible to correct for possible endogeneity in a satisfactory way. 
characteristics differential, while the second term to the right represents the coefficients differential.

The table shows that there are no significant variables in the training equation of flexible employees, but this is probably caused by the low number of flexible employees (who participated in a training course) in the data set used, so the estimates are not very efficient. The results for permanent employees are similar to the estimation results of the pooled sample in Table 2.

In Table 4, the Blinder decomposition of the training differential is shown. The results show that flexible employees turn out to have a two times lower participating rate in training than workers with a permanent contract. The larger part (over 60\%) of this differential is explained by differences in the characteristics of the workers. The rest of the training differential (almost $40 \%$ ) is explained by differences in coefficients, which indicates that firms are less willing to invest in the training of flexible workers than in their permanent workforce, even if both groups of workers have similar personal characteristics. Of course it is also possible that the flexible workers themselves are less prepared to participate in training activities. However, the stylised facts presented in Table 1 show that there is a remarkable difference in the financial support of firms in the human capital investments of their flexible and their permanent workforce.

Table $4^{*}$

Components of the training differential between flexible and permanent employees

Difference in training

$0.3783-0.1977=0.1806$

$0.3783-0.2653=0.1130$

$0.2653-0.1977=0.0676$
Percent difference

191.0

62.6

37.4

3) $\Phi\left(X_{f} \beta_{p}\right)-\Phi\left(X_{f} \beta_{f}\right)$

Rows are interpreted as follows: the first row shows the difference in training between permanent and flexible employees. Permanent employees have a 18.06 percentage point higher chance than flexible employees. This means that they have a $191 \%$ greater chance of attending training than their flexible counterparts. The second and the third rows show that permanent employees have a 11.3 percent point higher chance because of characteristics differentials and a 6.76 percent point higher chance because of different coefficients ("discrimination"). So $62.6 \%$ of the training gap can be attributed to differences in means and $37.4 \%$ to differences in coefficients.

\section{Conclusion}

In this paper, we tried to answer the question whether employees with flexible contracts receive less training than employees with permanent contracts, as could be expected from the relation-specific human capital model. We used a sample selection model to simultaneously estimate the determinants of attending continuing vocational training and the duration of 
training.

The estimation results indicate that flexible employees receive about half as much training as permanent employees. However, the flexible employees who do participate in training receive training of about the same length as permanent employees. As far as the duration of training can be interpreted as a measure of the quality of the training, one may conclude that the training courses in which flexible employees participate are at least of equal quality as the training courses that permanent employees attend.

We used a "Blinder-like decomposition" to decompose the training differential between flexible and permanent employees into a characteristics differential part and a coefficients differential part. Flexible employees appear to have a two times lower chance of participating in training than workers with a permanent contract. Over $60 \%$ of this differential can be explained by differences in the characteristics of the workers and almost $40 \%$ of the training differential is explained by differences in coefficients. The latter indicates that employers are less willing to invest in the human capital of flexible employees than in the human capital of their permanent workforce, even if both groups of workers have similar personal characteristics.

From an investment point of view, this lower investment in relation-specific human capital is understandable. For flexible workers, however, further investments in their human capital are even more important than for workers with permanent contracts, as the labour market position of flexible workers is continuously at risk. This provides an argument for facilitating training participation of flexible workers by means of government subsidies, e.g. by (partly) publicly financed training or by giving financial support for training participation of flexible workers in the form of educational loans at low interest rates. As argued in Section 2, flexible employees are then probably more willing to invest in their human capital because they do not have to bear all the costs.

\section{References}

Altonji, J.G. and J.R. Spletzer (1991), Worker Characteristics, Job Characteristics, and the Receipts of On the-Job-Training, International and Labour Relations Review, vol. 45, no. 1, pp. 58-79.

Amemiya, T. (1989), Advanced Econometrics, Basil Blackwell Itd., Oxford (first edition 1985).

Barron, J.M., D.A. Black and M.A. Loewenstein (1989), Job matching and On-the-Job Training, Journal of Labour Economics, Vol. 7, no. 1, pp. 1-19.

Bartel, A.P. (1992), Training, Wage Growth and Job Performance: Evidence from a Company Database, NBER Working paper, no 4027, Cambridge, Mass.

Becker, G. (1962), Human Capital: A Theoretical and Empirical Analysis, Journal of Political Economy, NBER Working Paper, no. 4027, Cambridge, Mass.

Becker, G.S. (1975), Human Capital, A theoretical and Empirical Analysis with Special Reference to Education, New York: Colombia University Press, second edition. 
Booth, A.L. and M. Chatterji (1995), Training and Contracts, Dundee Discussion Papers in Economics, no. 64, University of Dundee, Dundee.

Booth, A.L. and D.J. Snower (1995), Acquiring Skills, Market failures, their symptoms and policy

Cambridge University Press, Cambridge.

Broeder, C. den (1996), Institutions at work, Commitment and flexibility on the German and Dutch labour market, Research Memorandum no. 131, Centraal Planbureau, Den Haag.

Brouwer E., and A.H. Kleinknecht (1994), Innovatie in de Nederlandse industrie en dienstverlening, Ministerie van Economische Zaken, Den Haag.

CBS(1998), Enquete Beroepsbevolking 1997, Centraal Bureau voor de Statistiek, Voorburg/Heerlen. CBS (1995), Bedrijfsopleidingen 1993, Particuliere sector, Centraal Bureau voor de Statistiek, Voorburg/Heerlen.

Crawford, V.P. (1988), Long-Term Relationships Governed by Short-Term Contracts, American Economic Review, vol. 78, 485-499.

Crawford, V.P. (1990), Relationship-Specific Investment, Quarterly Journal of Economics, 561-574.

Delsen, L. (1995), Atypical Employment: An International Perspective, Wolters-Noodhoff, Groningen.

Eijs, P. van and H. Heijke (1999), 'Mismatch between Occupation and Education and the Costs and Benefits of Job-Related Training', in Heijke, H. and J. Muysken (eds), Education and Training in a Knowledge Based Economy, MacMillan, Houndmills, forthcoming.

Graaf, P.M. de, E.J.C. Josten, P.T. van den Berg and R. Luijcks, Informatietechnologie en kansen op werk, Tijdschrift voor Arbeidsvraagstukken, Vol. 11, no.1, pp. 7-20.

Green, F. (1993), The Determinants of Training of Male and Female Employees in Britain, Oxford $B$ of Economics and Statistics, Volume 55, $\mathrm{n}^{\circ} 1$, pp. 103-121.

Grip, A. de, M. van Smoorenburg, L. Borghans (1997), The Dutch Observatory on Employment and Training, ROA-RM-1997/2E, Maastricht.

Grip, A. de, H. Heijke, E. Willems (1998), Training and Mobility, The Netherlands' Journal of Social Sciences, Vol.34, no. 1, pp. 78-98.

Groot, L.F.M., J.J. Schippers, J.J. Siegers, The Effect of Interruptions and Part-Time Work on Women's Wage Rate: a Test of the Variable-Intensity Model, in: De Economist, vol. 136, no. 2, 1988 , pp. 220-238.

Groot W. and H. Oosterbeek (1995), Determinants and Wage Effects of Participation in On and Offthe-Job Training, Tinbergen Institute Discussion Paper 95-122, Amsterdam.

Hashimoto, M. (1981), Firm-Specific Human Capital as a Shared Investment, American Economic Review, vol. 71, 475-482.

Josten E., P.T. van den Berg, P.M. de Graaf and R. Luijkx (1995), Informatietechnologie en kansen op de arbeidsmarkt, Tijdschrift voor arbeidsvraagstukken, vol. 11, no. 1, 7-20.

Kunnen R., W.C.M. Praat and H.R.M. Smulders (1995), Trendrapport Aanbod van Arbeids 1995, 
Organisatie voor Strategisch Arbeidsmarktonderzoek (OSA), Den Haag.

Maddala, G.S. (1993), Limited-dependent and Qualitative Variables in Econometrics, Cambridge University Press, Cambridge.

Mincer, J. and H. Ofek (1980), Interrupted work careers, National Bureau of Economic Research, Working Paper no. 479, Cambridge

OECD (1998), Education at a Glance, Paris.

Olsen, R.N. and E.A. Sexton (1996), Gender Differences in the Returns to and the Acquisition of Onthe-Job Training, Industrial Relations, vol. 35, no. 1, 59-77.

Oosterbeek, H. (1996), Unraveling supply and demand factors in work-related training, paper presented at the LVIIth International Conference of the Applied Econometrics Association in Maastricht.

Prendergast, C. (1993), The role of promotion in inducing specific human capital acquisition, The Quarterly Journal of Economics, 523-534.

Psacharopoulos, G., (1987), The Cost-Benefit Model, In: Psacharopoulos, G. (ed.), Economics of Education, Research and Studies, Pergamon Press, pp. 342-347.

Stevens, M. (1994a), An investment model for the supply of training by employers, The Economic Journal, vol. 104, 556-570.

Stevens, M. (1994b), A Theoretical Model of On-the-job Training with Imperfect Competition, Oxford Economic Papers, vol. 46, 537-562.

Treu, T. (1992), Labour flexibility in Europe, International Labour Review, vol. 31, 497-512.

Veum J.R. (1996), Gender and Race Differences in Company Training, Industrial Relations, vol. 35 , no. $1,32-43$. 


\section{Appendix A}

Table Means and standard deviations of variables used for workers with permanent contracts and workers with flexible contracts

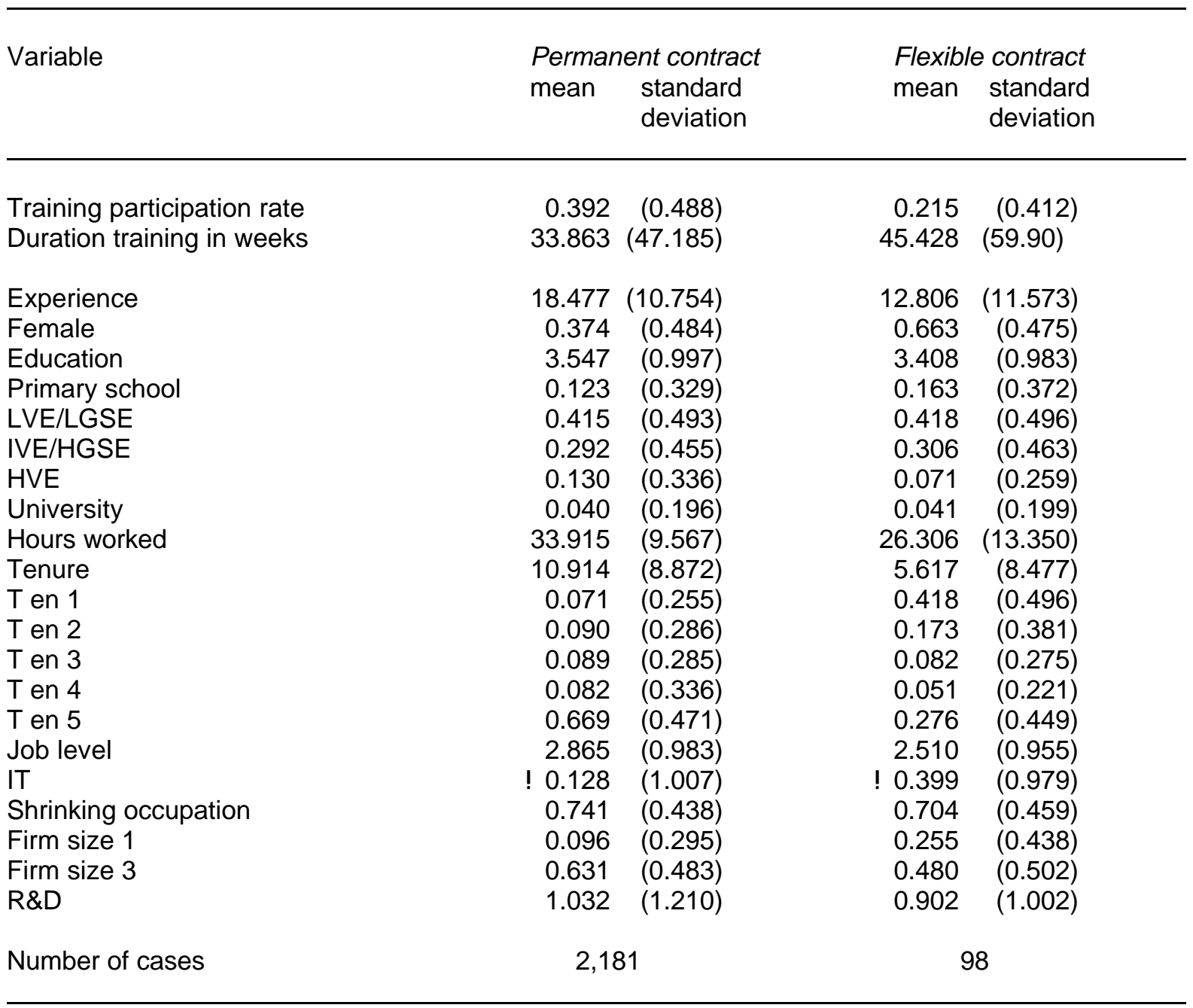

